\title{
An Anger-based Explanation of the Difference in Punishment between an Attempt and a Consummated Murder
}

\author{
Nascimbene J* \\ University of Chicago, USA
}

*Corresponding author: Juan Nascimbene, NY, USA; Email:

juannascimbene@gmail.com

\section{Commentary}

Volume 1 Issue 2

Received Date: September 11, 2018

Published Date: October 29, 2018

DOI: $10.23880 /$ phij-16000109

\section{Abstract}

Generally, attempted murders have a reduced punishment vis-a-vis murders. There has been a lot of debate between those who support this differentiation and those who oppose it because they claim that the acts are morally equivalent. This paper tries to explore a third route by suggesting that the differential in punishment may be associated with an Aristotelian conception of anger. However, we criticize this justification and we then show why a forward-looking conception of punishment should support an equivalent punishment for murders and complete murder attempts.

Keywords: Anger; Consummated Murder; Punishment; Aristotle’s theory

\section{Introduction}

Imagine four individuals: $A, B, C$ and $D$. Individual $A$ shoots at a three-meter distance at $B^{\prime}$ s forehead with the intent to kill her. Simultaneously, $C$, who is standing next to $A$, shoots at exactly the same distance aiming at $D^{\prime}$ s forehead. From an ex-ante perspective, we would say that $A^{\prime}$ s and $C^{\prime}$ s actions are identical. Now suppose that $A^{\prime}$ s bullet penetrates $B^{\prime}$ s head and kills her while $C^{\prime}$ 's bullet is deviated from hitting $D$ 's head by a very strong wind and as a result $D$ gets lightly injured. Ex-post, the agents' actions would be punished differently in almost all jurisdictions around the world. That is to say, while $A$ would be convicted for murder, $C$ would be convicted for attempted murder, which would entail a lower sentence. But, if ex-ante their actions were morally equivalent and if from an agency perspective, $\mathrm{C}$ did nothing to prevent saving $D$, why should $C$ have a lower punishment than $A$ ?

Philosophers and criminal law scholars have long debated this question. There are those who support the dominant status quo "difference thesis" by which criminal attempts should have less punishment than consummated crimes $^{1}$. In contrast, there are others that defend the "equivalence thesis" sustaining that both actions are worthy of the same punishment ${ }^{2}$.

The debate comprises very sophisticated arguments with very little compromise on both sides ${ }^{3}$. And, although our intuitive reaction is to consider that consummated crimes should be worthy of a higher punishment than attempts, that divergence seems to be sustained in some sort of magical thought. Going back to our example, why should $A$ be more blameworthy than $C$ when they executed exactly the same kind of reprehensible action?

\footnotetext{
${ }^{1}$ Michael S Moore, The Independent Moral Significance of Wrongdoing, J. of Contemp. Legal Studies 237(1994) 238; George Fletcher, A Crime of Self-Defense: Bernhard Goetz and the Law on Trial 82 (1988).

${ }^{2}$ Joel Fienberg, Doing And Deserving 33 (1970); Hyman Gross, A Theory Of Criminal Justice 423-36 (1979).

${ }^{3}$ Some authors have even questioned whether there is a compelling argument on this debate. See Bjorn Burkhardt, Is There a Rational Justification for Punishing an Accomplished Crime More Severely Than an Attempted Crime?, BYUL Rev 553 (1986) 556.
} 
This is what the difference thesis's proponents cannot fully explain. Departing from culpability and blameworthiness, some have tried to explain it by recurring to deterrence arguments ${ }^{4}$. But this justification doesn't seem to be sound enough since, from a deterrence perspective, the punishment affects the individual's exante conduct ${ }^{5}$. Hence, aggravating the sentence ex-post in case the offender succeeds in killing someone cannot truly influence on her decision to shoot in the first place.

Alternatively, we will suggest that the difference in punishment may be associated with a feeling of anger in an Aristotelian way. Indeed, from the victim family's point of view, the anger and the "payback" feeling is greater when their relative is dead than when she was almost killed. Nevertheless, this seems shortsighted and very much based on a retributive notion of the law, which doesn't seem to be constructive. A note of caution is needed: it is not our contention that most defenders of the difference in punishment have been directly influenced by Aristotle, rather we suggest that they resort to a retributive conception of anger which is similar to the way that Aristotle had originally conceived it.

Conversely, if we were to adopt a more forwardlooking conception on punishment related to TransitionAnger 6 , detaching ourselves from the "payback" feeling, there would be of good reason to treat a complete attempt as less blame-worthy than a consummated crime.

Note that we are not saying that the complete murder attempt should have a higher punishment. We are only stating that whatever the punishment that a society deems to be applicable for a murder should the same as for a complete murder attempt ${ }^{7}$. Additionally, although the equivalence thesis could extend to all types of crimes, for the sake of this paper, we will refer to the equivalence between a murder attempt and a murder.

The structure of the paper will be as follows. Section II will summarize the debate between those who support

\footnotetext{
${ }^{4}$ For a greater discussion on the deterrence arguments discussion see Section IV.A.

${ }^{5}$ For example, Hart HLA writes that there "seems to be no reason on any form of deterrent theory...for punishing the unsuccessful attempt less severely tan the completed crime." Hart HLA, Intention and Punishment, Oxford Rev. 5 (1967), reprinted in punishment and responsibility 113 (2008) 130.

${ }^{6}$ Martha C Nussbaum, Anger and Forgiveness: Resentment, Generosity, Justice 16-17 (2014).

${ }^{7} \mathrm{By}$ complete attempt we refer to those attempts where the individual has done all the necessary actions for the result of the murder to occur and yet the crime was not consummated for exogenous circumstances that the person could not have controlled.
}

the "difference thesis" versus those who sustain the "equivalence thesis". Then, in Section III, we will suggest that the harsher punishment for murders could be rooted in a feeling of "payback" and retribution, which is somewhat similar to Aristotle's notion of anger. However, as suggested by professor Nussbaum, this conception of anger is not forward-looking and involves some sort of magical thought ${ }^{8}$. Thus, in Section IV we will discuss why the equivalence thesis is consistent with a forwardlooking framework for punishment. In this section, we will also evaluate how the equivalence thesis is compatible with deterrence, specific deterrence and communicative criminal law purposes. Lastly, in Section V we will evaluate possible objections to our position and respond to them.

\section{The Debate between the Equivalence and the Differentiated Punishment Theses}

The debate on whether attempted murders should have the same punishment as a consummated one goes as far as Plato. In the Laws, he writes:

"If anyone has a purpose and intention to slay another who is not his enemy, and whom the law does not permit him to slay, and he wounds him, but is unable to kill him, he who had the intent and has wounded him is not to be pitied-he deserves no consideration, but should be regarded as a murderer and be tried for murder. Still having respect to the fortune which has in a manner favoured him, and to the providence which in pity to him and to the wounded man saved the one from a fatal blow, and the other from an accursed fate and calamity-as a thank-offering to this deity, and in order not to oppose his will-in such a case the law will remit the punishment of death, and only compel the offender to emigrate to a neighbouring city for the rest of his life, where he shall remain in the enjoyment of all his possessions. But if he have injured the wounded man, he shall make such compensation for the injury as the court deciding the cause shall assess, and the same judges shall decide who would have decided if the man had died of his wounds"9.

The Greek Philosopher considered that the individual who attempts a murder is as morally responsible as the one who commits one. As he suggests, the attempted murderer should be judged as a murderer and make compensations as if she had killed the victim. However, he

\footnotetext{
${ }^{8}$ Nussbaum supra note 6.

${ }^{9}$ Plato, The Laws, Book IX,

$<$ http://classics.mit.edu/Plato/laws.9.ix.html> (emphasis added).
} 
concedes that the punishment by death could be forfeited only as a matter of fortune.

The influence of luck in the way in which society holds people accountable is a much-debated concept since the eruption of the Williams-Nagel debate on moral luck ${ }^{10}$. Those who defend the influence of luck in the way in which a person should be punished suggest that randomness has a major impact in our lives' decisions ${ }^{11}$. Accordingly, moral luck implies that one could be held accountable for events that are beyond our control. In the criminal law, this translates to supporting the difference in punishment for attempts vis-à-vis murders. This will be referred to as the "difference thesis" position. Those who take this approach believe that it is not equivalent to cause a result than to only attempt it ${ }^{12}$.

On the other hand, those who support the "equivalence thesis" sustain the idea that attempts should be punished equivalently to consummated crimes ${ }^{13}$. The main argument behind this line of thought lies in not holding an individual accountable for matters that are completely beyond her control since they are determined by luck ${ }^{14}$. As Sverdlik puts it: "...then it seems as if we are permitting that the moral responsibility of a person could be affected by, let's say, the unexpected and uncontrollable flight of a bird"15.

There are various characterizations of positions in favor of this latter thesis, but overall, a good summary has been portrayed by Michael Moore -who incidentally opposes this position -: "It cannot matter to an offender's just deserts whether the wind, a bird, or a quantum shift moved the bullet that an offender sent on its way, intending to kill another, for these causal influences are

\footnotetext{
${ }^{10}$ Bernard Williams, Moral Luck: Philosophical Papers 1973-1980 23 (1981); Thomas Nagel, Mortal Questions 24 (1979).

${ }^{11}$ Leo Katz, Why the Successful Assassin Is More Wicked than the Unsuccessful One, Cal L Rev 791 (2000) 792.

${ }^{12}$ George Fletcher, Rethinking Criminal Law 472-83 (1978); Michal Davis, Why Attempts Deserve Less Punishment than Complete Crimes, Law \& Phil 1 (1986).

${ }^{13}$ Larry Alexander \& Kimberly Ferzan, Crime and Culpability, A Theory of Criminal Law (2009); Larry Alexander \& Kimberly Kessler Ferzan, Results don't matter, in Paul H. Robinson, Stephen Garvey \& Kimberly Kessler Ferzan (Eds.), Criminal Law Conversations (2011); Andrew Ashworth, Belief, Intent, and Criminal Liability, in Eekelaar\& Bell (eds.), Oxford Essays in Jurisprudence (1987).

${ }^{14}$ Heart HLA, Punishment and Responsibility: Essays in the Philosophy of Law (1988) 129-131; Joel Feinberg, Equal Punishment for Failed Attempts: Some Bad But Instructive Arguments Against It, Ariz. L. Rev. 118-119 (1995).

${ }^{15}$ Steven Sverdlik, Crime and Moral Luck. American Phil Quart 80 (1988).
}

wholly beyond the control of the offender. What he can control is whether he intends to kill and whether he executes that intention in a voluntary action of moving his finger on the trigger; all the rest is chance. The offender deserves to be punished only for factors he can control, not for chance events he can't control" 16 .

It is undeniable, as most of the supporters of the difference thesis hold, that results are important for our everyday life ${ }^{17}$. We don't care if our favorite sport team played very well; we care if it won the match. However, this doesn't seem to be easily extrapolated into a person's moral accountability for a crime ${ }^{18}$. We do care if the person was acting in accordance with the law or not. We care if her conduct can be modified and prevented. That is why luck should not explain a punishment differential. As Professor George Fletcher acknowledges: the main argument in favor of a differentiated punishment lies in intuitions and cannot be fully articulated in rational terms ${ }^{19}$.

In effect, the defenders of the difference thesis cannot fully give an account for the surplus in punishment, which is merely attributed to the occurrence of a prohibited result ${ }^{20}$. In the following section, we suggest that this could be explained by relying on retributive conceptions of anger, which are akin to Aristotle's conception of anger.

\section{Justifying the Difference Thesis by Relying on the Classical Aristotelian Account of Anger}

As Professor Schulhofer stated: "[a] policy so pervasive and important as the law's emphasis upon

\footnotetext{
${ }^{16}$ Michael S. Moore, supra note 1, at 239.

${ }^{17}$ See Michael Moore supra note 1.

${ }^{18}$ Kimberley Ferzan \& Larry Alexander, Results don't mattersupra note 13 at 153 ("Although many people believe that results matter, there is a distinction to be drawn between results mattering (as they must because they affect the world in which we live) and results mattering for the moral blameworthiness of the actor.")

${ }^{19}$ George P Fletcher, The Nature of Justification, In Steven Schute et al., Action and Value in Criminal Law 175 (1993) 179 ("Admittedly, there might be stronger arguments for a position that seems so deeply entrenched in the world's legal culture. Generating a convincing rationale...reminds one of other practices of the criminal law that are widely shared and intuitively accepted-for example, punishing completed crimes more severely than attempts...-but for which theoreticians have yet to generate a compelling justification.").

${ }^{20}$ As David Lewis concedes: "It is hard to find any rationale for our leniency toward the unsuccessful [attempter]". In this passage he is comparing the successful attempted (the one who consummates the crime) versus the unsuccessful one (the one who fails at producing the forbidden result). See David Lewis, The Punishment That Leaves Something to Chance, Phil \& Pub Aff 53 (1989).
} 


\section{Philosophy International Journal}

results might reasonably be expected to stand upon some fairly weighty reasons capable of coherent explanation" 21 . Nonetheless, as we have seen in the previous section, the difference thesis' supporters cannot give a complete account justifying their position. Alternatively, we will suggest that what lies behind this differentiation could be rooted in a conception of retribution and anger in an Aristotelian sense as expressed by the victim or the victim's close circle (family, relatives and friends).

Aristotle believed that anger is "a desire accompanied by pain for an imagined retribution on account of an imagined slighting inflicted by people who have no legitimate reason to slight oneself or one's own"22. As suggested by Professor Nussbaum, there are five elements to the Aristotelian conception of anger: ${ }^{23}$

\section{Slighting or down-ranking}

2. Of the self or people close to the self

3 . Wrongfully or inappropriately done

4. Accompanied by pain

5. Involving a desire for retribution

Now, if we were to apply these criteria to the family of a victim of a murder versus the family of a victim of an attempted murder, there would be a difference in the degree of anger that each would feel. The anger process, according to Aristotle's account, causes "pain to the self" when the person experiences the sensation that something which she is deeply concerned for (such as an individual) was harmed ${ }^{24}$. Accordingly, there are two factors that may create an anger-intensity difference between the attempt and the murder.

First, in terms of down ranking, the family may feel more down-ranked if their relative was killed than only injured or attempted to be killed. Thus, they would like the criminal to be slighted even more in the former case than in the latter.

Second, the pain followed by the murder is invariably stronger than the pain followed by the attempted murder. Indeed, the widow and children of the deceased would feel angrier if their husband or father is killed than if he was attempted to be killed. Consequently, and thinking in

\footnotetext{
${ }^{21}$ Stephen J Schulhofer, Harm and Punishment: A Critique of Emphasis on the Results of Conduct in the Criminal Law, 122 U Pa L Rev 1497 (1974) 1514.

${ }^{22}$ Aristotle, Rhetoric as cited in Martha C. Nussbaum, supra note 6, at 16-17 (2014).

${ }^{23}$ Nussbaum supra note 6 , at 17 .

${ }^{24}$ Nussbaum supra note 6 at 18 .
}

terms of lex talionis, the desire for retribution is greater in the murder case given that the "payback is seen as somehow assuaging the pain or making good the damage" 25 .

Hence, the defenders of the differential punishment theory could rely on an Aristotelian conception of anger to explain the difference in punishment. This is much more so given that Aristotle thinks that what is relevant is the way in which the affected person feels the anger, "not the way it really is, which might, of course" be different ${ }^{26}$. Note that we do not contend that the supporters of the differential thesis explicitly cite or have been influenced by Aristotle. However, those who heavily rely on retributive conceptions of punishment to support a differential thesis cite anger or "down-ranking" as a major justification for so believing it. Although they haven't cogently framed their arguments in an Aristotelian way, they very well could do so.

Moreover, the belief that the degree in anger can explain a differential between the attempt and the consummated murder could be confirmed by findings in social psychology. For example, studies have shown that individuals who feel angry tend to allocate more punitive damages in tort cases than those that are in a neutral position ${ }^{27}$. In addition, anger thoughts of blame can quickly escalate so that the more anger, the more blame is placed on a certain individual ${ }^{28}$. Consequently, if one feels angrier towards a murderer than towards an attempter, one would ascribe more blame on the former and believe that it is intuitively correct to demand more punishment in that case.

Various scholars have tried to specifically justify the punishment based on the victim's or victim families' thrive for payback and revenge. Indeed, the recent victim's rights movements "appear to be driven more by the retaliatory view of retribution" 29 . Some have even claimed that revenge is a key aspect of "our very human moral psychology" and it shapes our vision on justice ${ }^{30}$. In

\footnotetext{
${ }^{25}$ Nussbaum supra note 6 at 21 .

${ }^{26}$ Nussbaum supra note 6 at 17-18.

${ }^{27} \mathrm{Goldberg} \mathrm{JH}$, et al., Rage and reason: the psychology of the intuitive prosecutor, Eur J of Soc Psych 781(1999).

${ }^{28}$ Tedeschi JH, Quigley BM (1996) Limitations of laboratory paradigms for studying aggression. Aggression and Violent Behavior: A Review Journal, J of Applied Social Psychology 163.

${ }^{29}$ Lynne N Henderson (1995) The Wrongs of Victim's Rights, Stan L Rev 937: 994.

${ }^{30}$ Ken Levy (2014) Why Retributivism Needs Consequentialism: The Rightful Place of Revenge in the Criminal Justice System, Rutgers L Rev 629: 656 .
} 


\section{Philosophy International Journal}

fact, in Furman v. Georgia, Justice Stewart's concurrence stated "channeling [vengeance] in the administration of criminal justice serves an important purpose in promoting the stability of a society governed by law" 31 . This is an institutional way of expressing the Aristotelian conception of "down-ranking" that emerges from the feeling of anger.

Additionally, this account could also be supported by certain retributive theories of punishment ${ }^{32}$. For example, Michael Moore relies on the satisfactory anger-soothing feelings of friends and families of murdered victims to support the rightfulness of retaliatory Statepunishments ${ }^{33}$. Thus, under Moore's account, as the victim's family needs more anger-soothing when the victim has been killed, their crave for punishment would be higher in that case compared to the attempt. Herbert Morris' more nuanced retributivism makes the claim that the liberty that the offender took from the killed victim is greater than the one that it took from the victim that was not killed ${ }^{34}$. Thus, the proportionality in punishment is greater in the murder than in the attempted murder ${ }^{35}$.

Accordingly, if we accept this "justice as vengeance" account as valid, which we do not (as argued below), then this could be a more plausible explanation for a differential punishment between attempts and murders. But, even though the difference in punishment between attempts and murders could rely on retaliatory anger, it "owes much, even perhaps everything, to one of two pernicious errors: either to a fruitless focus on magical ideas of payback, or to an underlying obsession with relative status, which is the only thing that really makes sense of retaliation as ordinarily conceived" 36 . In this vein, we believe that the punishment difference is based in a sort of magical idea of payback, which is corrosive for the criminal system.

\footnotetext{
${ }^{31}$ Furman Georgia (1972) 408 U.S. 238, 308.

${ }^{32}$ It must be noted that some scholars who support the equivalence thesis rely also are proponents of the equivalence thesis. For example see: Kimberly Ferzan \& Larry Alexander supra note 13.

${ }^{33}$ Michael S Moore (1995) The Moral Worth of Retribution, in Punishment and Rehabilitation, in Jeffrie Murphy (Ed.), Punishment and Rehabilitation 98-99.

${ }^{34}$ As he writes: "the consummator owes more because he has taken and acquired more. He has not just the satisfaction attendant upon realization of his desires". Herbert Morris, On Guilt and Innocence 127 (1976) See also Nussbaumsupra note 6, at 184.

${ }^{35}$ Morris Id.

${ }^{36}$ Nussbaum supra note 6 at 31 .
}

\section{The Equivalence Thesis as a More Rational Approach in a Forward-Looking Framework of Punishment}

The criminal justice system cannot avail itself of the expression of past looking retributive punishments based on anger. "Political institutions should not embody incoherent and normatively defective ideas" ${ }^{37}$. In effect, as suggested by Professor Nussbaum, the more rational, forward-looking type of anger that we should try to cultivate in our society is Transition-Anger. This type of anger "does not focus on status; nor does it, even briefly, want the suffering of the offender as a type of payback for the injury. It never gets involved at all in that type of magical thinking. It focuses on social welfare from the start. Saying, "Something should be done about this," it commits itself to a search for strategies" 38 .

In this framework, an influential XIX century Italian writer, Gaetano Filangieri, sustained that murders should have the same punishment as that of the attempted murder since the latter embodies the action which is forbidden by the law ${ }^{39}$. Citing Plato, he suggests that in punishing we must prevent the impulse of "irrational vengeance like a beast" 40 . On the contrary, punishment should focus on re-establishing security and in the rehabilitation of the criminal ${ }^{41}$.

In accordance, Justice Stewart's demand to vent vengeance through criminal system by channeling the victim's anger and resentment seems to be an incorrect approach. The purpose behind the victim's or the victim's family expression of their anger within the framework of the criminal trial "simply serves to whip up retributive emotion" 42 . This does not resuscitate the dead person or allows the family to move forward ${ }^{43}$. It only promotes a spiral of payback and retribution.

Institutions, to the contrary, should pursue different kinds of forward-looking strategies such as general deterrence, specific deterrence, and communicational goals ${ }^{44}$. As shown below, under these types of punishment

\footnotetext{
${ }^{37}$ Nussbaum supra note 6 at 176 .

${ }^{38}$ Nussbaum supra note 6 at 176 .

${ }^{39}$ Gaetano Filangieri, La Ciencia de la Legislación 221-226 (1836).

${ }^{40} I d$.

${ }^{41} I d$.

${ }^{42}$ Nussbaum supra note 6 at 195.

${ }^{43}$ Id.

${ }^{44}$ Professor Nussbaum writes: "[Institutions]...ought to take wrongful acts seriously, seek to prevent them, and attend to them if they occur" Nussbaum supra note 6 at 31 .
} 


\section{Philosophy International Journal}

theories, there isn't any good reason to justify a punishment differential between attempts and murders.

\section{General Deterrence}

The general deterrence theory is built around the idea that criminal punishment acts as deterrence for future criminals who want to engage in a certain criminal activity. From this perspective, a differential approach between attempts and consummated crimes is not coherent given that what the criminal law aims to deter is the conduct ${ }^{45}$. Criminal law cannot have an impact on whether the result occurs or not given that this is a question that is left to luck not to conduct modification.

However, proponents of the differential punishment thesis generally rest on three deterrence arguments to justify their position. We will show how each of them fails to attain their goal.

First, Judge Richard Posner says that punishing attempted murders and murders differently rest on the marginal incentives provided to the unsuccessful criminal. As he writes: "If the punishment for attempted murder were the same as for murder, one who shot and missed (and was not caught immediately) might as well try again, for if he succeeds, he will be punished no more severely than for his unsuccessful attempt" 46 .

The problem with Posner's argument is that it assumes that the criminal who shot and missed will be dissuaded to continue shooting by the difference in punishment. This doesn't seem to be a plausible explanation of the criminal's conduct specially if he shot in the first place. Furthermore, it overlooks the fact that before taking the first shot, the individual had many incentives to desist that he overlooked given that most jurisdictions have defenses to those who discontinue a criminal act before the attempt is complete ${ }^{47}$.

\footnotetext{
${ }^{45}$ David Schmidtz, Deterrence and Criminal Attempts, Canadian Journal of Philosophy, 615 (1987) ("Criminal sanctions are directed against types of conduct, not against particular tokens of conduct. The subject of the sanction, the wrongdoing, consists in the conduct, not the result of the conduct. As wrongful conduct, fortuitously thwarted attempts and analogous success are all of the same type...The difference in result between completed and fortuitously thwarted instances of a given mode of criminal conduct is ascertainable only in retrospect." at 622-623); See also Hart HLA, supra note 6, at 130.

${ }^{46}$ Richard A. Posner, An Economic Theory of the Criminal Law, Colum L Rev 1193 (1985).

${ }^{47}$ For example see Model Penal Code § 5.01(3) (Am Law Inst Proposed Official Draft 1962). This defense is available if it was the result of a voluntary renunciation see Model Penal Code $\S 5.01(4)$.
}

The second deterrence-based justification that proponents of the differential punishment thesis have put forward is the "penal lottery argument" 48 . As people are risk averse, randomly punishing some people more severely and others more leniently would deter crime more efficiently than punishing attempters and murderers equally ${ }^{49}$. Although this is an interesting point, it is mainly an empirical claim. Recent empirical literature "indicate[s] that increases in the certainty of punishment are more effective deterrents than increases in the severity of punishment" 50 . Accordingly, the uncertainty assumption on which this argument is construed has not been fully empirically proved. Further, it doesn't seem to be the case that the higher the punishment, the higher the level of deterrence.

Lastly, some have tried to use Bentham's utilitarian deterrence theory to justify a consequentialist defense of the differential thesis ${ }^{51}$. Bentham's work refers to the idea that punishment should be tailored to each particular crime $^{52}$. For example he stated that the punishment for "a man's giving you ten blows" should be harsher than that for a man who gives you less blows because otherwise the criminal "will be sure to give you five more, since he may have the pleasure of giving you these five for nothing" 53 . Accordingly, Bentham is saying that a person that commits the action of giving you ten blows should be more severely punished than a person that commits the action of giving you five blows. We do not dispute this argument. Rather we say that the person who commits the action of throwing ten blows should be punished in the same way regardless of whether those 10 blows hit the target or not. This is because what we want to deter is the action of endeavoring those blows in the first place.

\section{Rehabilitation and Reform}

The theory of rehabilitation and reform aims to rehabilitate an individual after she committed a crime in order to prevent future crimes once she is reinserted into society. This could take various forms such as being

\footnotetext{
${ }^{48}$ Vincent Chiao, Ex Ante Fairness in Criminal Law and Procedure, New Crim L Rev 277 (2012) 279.

${ }^{49}$ Doron Teichman, The Optimism Bias of the Behavioral Analysis of Crime Control, U Ill L Rev 1697 (2011) 1700.

${ }^{50}$ Guyora Binder (2008) The Culpability of Felony Murder 83 Notre Dame L Rev 965: 982 see also Daniel S. Nagin, Deterrence in the Twenty-First Century, Crime \& Just. 199, 201 (2013).

${ }^{51}$ Russel Christopher, Does Attempted Murder Deserve Greater Punishment than Murder - Moral Luck and the Duty to Prevent Harm, Notre Dame J L Ethics \& Pub Pol'y 419 (2004) 420.

${ }^{52}$ Jeremy Bentham, An Introduction to the Principles of Morals and Legislation 168 (Burns JH \& Hart HLA eds. 1996) (1781).

${ }^{53}$ Id.
} 
reeducated in prison and other facilities ${ }^{54}$ or Braithwaite's parent-like reintegration process ${ }^{55}$. In order for the differential punishment approach to be compatible with this theory, the successful attempter (the murderer) should need more rehabilitation or reform than the unsuccessful attempter. But this doesn't seem to be the case.

The rehabilitation process should focus on the individual's background, her motivation for acting against the law, her psychological state and how to prevent her choice to engage illegal conduct in the future ${ }^{56}$. Accordingly, the amount of rehabilitation that the offender that succeeds in her enterprise of killing needs does not seem to be different from the amount of rehabilitation of the unsuccessful one, all other factors equal. Society wants to rehabilitate those individuals that engage in intentional actions that have a risk of producing an illegal result, in this case death.

Indeed, rehabilitation or reform finds a parallel in children upbringing. For example, imagine that twins are playing in their garden with two identical baseballs that they intentionally throw against the neighbor's window because they have a grudge against him ${ }^{57}$. As a result of this, the window is broken by only one of the two baseballs. But, as they are identical, the neighbor does not know which of the two twins actually produced the harm. When the mother of the twins learns about this incident, she chooses to apply the same punishment to both children because they did not respect their neighbor's property. She does not really inquire who actually caused the broken window in the natural sense. She wants her children to improve their conduct and respect the neighbor's property in the future ${ }^{58}$.

\section{Communicational theories}

Both R.A. Duff and Dan Markel developed "political communicational theories of punishment". These theories

\footnotetext{
${ }^{54}$ We will assume that prisons, unlike their current functioning, serve to rehabilitate prisoners and allow them to smoothly be reinserted into society. We will leave behind empirical criticisms to the rehabilitation and reform methods in assuming that these can be fixed. For criticisms to rehabilitation see Richard Lowell Nygarrd, Crime, Pain, and Punishment: A Skeptic's View, Dick L. Rev. 355 (1998).

${ }^{55}$ John Braithwaite, Crime, Shame and Reintegration (1989).

56Stephen J Schulhofer, supra note 21 at 1601.

${ }^{57} \mathrm{~A}$ similar example is portrayed by Kimberley Ferzan \& Larry Alexander, Results don't mattersupra note 10 at 149 (2011).

${ }^{58}$ As Professor Nussbaum explains, the mother engages in a form of Transition-Anger in the sense that she doesn't punish as retaliation but rather to generate better conduct in their children. Nussbaum supra note 6 , at 46 .
}

focus on "calling into account" the individual for a past wrong but with the purpose of signaling that the law is committed to its own values ${ }^{59}$. Under this perspective, the individual should be called into account for one of her conducts that breached the basic norms that society has set upon itself ${ }^{60}$. Recalling our example in the introduction, under this account, when $\mathrm{C}$ is taking the shot against D's head, C is communicating that she doesn't care about the rule prohibiting murdering. The fact that her shot does not kill D is irrelevant from a communicative perspective. Society should call C into account for her utter disregard of the rule that forbids murdering. Society should not care whether she was successful or not in accomplishing that result because $\mathrm{C}$ has disregarded the community's basic commitment not to engage in intentional actions that have a high risk of producing a death.

Nevertheless, Duff does believe that there should be a difference between murders and attempts ${ }^{61}$. This may be guided by his conviction that punishment has a retributive core: "the guilty deserve to suffer (something), and...a proper aim for the criminal law is to subject them to that suffering"62. By engaging in this approach, he commits himself to the past-looking, anger-satisfying enterprise of retributivism and thus, it may seem intuitive to support the differential thesis.

However, the core-concept of Duff's theory of calling into account for a wrongful act, and to avoid repetition, is forward-looking63. Under this account, the criminal law should call individuals into account for a conduct and not for a result and that is why the occurrence of the victim's death should have no bearing in the difference in punishment. Similarly, under a reform-oriented interpretation of Markel's theory, ${ }^{64}$ the criminal who has attempted a murder should be called into account to be reformed in the same way as the one who has succeeded in doing so because the latter has assumed the risk of being successful.

\footnotetext{
${ }^{59}$ See Antony R Duff, Punishment, Communication, and community 22 (2001).

${ }^{60}$ Id.

${ }^{61}$ Antony R Duff, Subjectivism objectivism and the role of theory. In Simester/Smith (eds.), Harm and Culpability (1996); Antony R. Duff, Criminal Attempts (1996).

${ }^{62}$ As reproduced in Nussbaum supra note 6, at 189.

${ }^{63}$ Id.

${ }^{64}$ Nussbaum interprets Markel's theory "under its best light" to suggest that it has a forward looking reform perspective. See Nussbaum supra note 19, at 190.
} 


\section{Philosophy International Journal}

Another philosopher, Jane Hampton, developed an expressive theory of punishment from a teaching mechanism perspective. Namely, she purports to teach the criminal and society "the moral reasons for choosing not to perform an offense" 65 . Consequently, as Hampton focuses on the reasons behind the decision to perform an offense, her theory is completely compatible with the equivalence thesis. Indeed, the teaching mechanism that she describes deals with the conduct of the offender, not on whether she was successful in producing the result. If the conduct exhibits a profound disregard for the human life, it is important to make a statement to affirm society's commitment with the wrongfulness of that disregard ${ }^{66}$. As there is no true difference between the disregard for human life exhibited by the attempter versus the murderer, Hampton's communicative theory is more compatible with an equivalent punishment approach.

\section{Answering Possible Objections}

\section{A. If the punishment is the same for attempts and murders, the individual will have no incentive to prevent the occurrence of the result after the attempted crime}

Objectors to the equivalence thesis argue that in case the attempted murder is punished in the same way as the murder, the criminal will have no incentive to prevent the result from occurring ${ }^{67}$. For example, if an individual wanted to kill another one by aiming at her head and for an exogenous reason she ends up injuring the victim, she will have no incentive to prevent the victim's death if punished as a murderer. There are two possible responses to this objection.

First, it is unclear that that an individual who wanted to shoot somebody at the head will be motivated to act knowing that if the result is prevented, she will get a lower sentence.

Second, even taking for granted the possibility of motivating the criminal to prevent the result, the equivalence thesis is compatible with a reduced sentence for those individuals who have prevented the result from occurring. Nevertheless, this reduced punishment would be independent from moral worthiness and it would be

\footnotetext{
${ }^{65}$ Jane Hampton, The Moral Education Theory of Punishment, Philosophy \& Public Affairs 203 (1984)

${ }^{66}$ Nussbaum supra note 6 , at 191.

${ }^{67}$ Russell Christopher supra note 48. This is a part of Michael Moore's justification for the difference in punishment see Michael S. Moore, Placing Blame: A theory of the Criminal Law 225-227 (2010).
}

associated with other reasons of criminal policy, for instance the importance of preventing a death. But this does not support the differential thesis' position where an attempted murder should always have less punishment than a consummated one. This leads to absurd consequences of favoring even those criminals who have not helped their victims or that could have even thought that they were dead when they left the crime scene.

\section{$B$. The attempted murderer feels less guilt and remorse than the actual murderer}

George Fletcher advances a theory based on the emotions of the perpetrator to explain the differential punishment from the criminal's perspective ${ }^{68}$. Indeed he says that the murderer feels guilt and remorse while the attempted murderer fells shame, not guilt ${ }^{69}$. This explains the punishment differential.

However, consistently with Professor Feinberg's reply, ${ }^{70}$ we believe that both the attempted murderer and the murderer may feel guilt if they are not psychopaths. It may be true that the successful criminal may feel more guilt than the unsuccessful one. This is much more so since guilt is an emotion that is linked to a causal connection between an action and the damage produced from that action $^{71}$. From this perspective, when the person kills there is actually a dead person. Thus, the murderer will feel more guilt than the one who attempted to murder who has not caused a death in the natural sense.

However, believing that we must punish someone more harshly due to the fact that she feels more guilt is not a forward-looking conception of criminal law. To the contrary, it seems to be portrayed as a religiously justified punishment based in the expiation of past sins.

Furthermore, some psychological studies have pointed to the fact that the guilt associated with causing harm to others is not related to self-ascription of culpability but rather it is a way of expressing empathy towards our victims $^{72}$. For example, even if we were driving at a

\footnotetext{
${ }^{68}$ Fletcher supra note 12 , at 482.

${ }^{69}$ Id.

${ }^{70}$ Feinberg, Equal Punishmentsupra note 14 at 125-127.

${ }^{71}$ See John Deign, The Sources of Moral Agency 42-43 (1996); Gabriele Taylor, Pride, Shame, and Guilt: Emotions of Self-Assessment 93 (1985).

${ }^{72}$ Guyora Binder, Victims and the Significance of Causing Harm, Pace L Rev 713 (2008) 732.
} 
reasonable speed, we may still feel guilty if we kill a child who unexpectedly jumps in front of us ${ }^{73}$.

Consequently, the guilt that the offender feels is not a good justification for the punishment differential because it is not a sufficient nor necessary condition for culpability and it is not a forward-looking strategy.

Now, Braithwaite does think of the guilt of the offender in a transitional way ${ }^{74}$. He proposes to use the guilt constructively to reintegrate the criminal into the community ${ }^{75}$. This is a forward-looking approach to punishment. The key difference to the way in which Fletcher conceives guilt is that Braithwaite does not purports to punish based on the offender's guilt but rather he wants to use it as a tool for reform.

\section{The differential punishment is based on the harm that occurred in the murder, which is inexistent in the attempt.}

Some scholars have claimed that the attempted murder cannot have the same punishment as the murder since there was no actual harm in the first crime ${ }^{76}$. Nonetheless, this argument is misguided.

Joel Feinberg identifies a clear response to this objection, ${ }^{77}$ which is very similar to the justification we gave on why the deterrence theory of punishment is consistent with the equivalence thesis. As he points out, the criminal law tries to combat the harms that may derive from an action or a conduct. Those are the only human behaviors that can be effectively deterred. The law cannot deter the result given that it has no influence on whether it will occur or not. This is a sphere that is reserved to luck.

Professor Kadish has even considered that the "Harm Principle" may sometimes lead us to irrational

\footnotetext{
${ }^{73} \mathrm{~A}$ similar argument is advanced by Herbert Morris, Nonmoral Guilt, in Ferdinand Schoeman (Ed.), Responsibility, Character, and the Emotions 200 (1987).

${ }^{74} \mathrm{He}$ calls this process "guilt-induction". See John Braithwaite, Crime, Shame and Reintegration 57-58 (1989).

${ }^{75}$ Id.

${ }^{76}$ LaFave and Scott, Criminal Law 9 (1972).

${ }^{77}$ Joel Feinberg, Problems at the Root of Law - Essays in Legal and Political Theory 82 (2003). He writes: "This statement formulates the liberal theory of the proper limits of the criminal law, and is close to a principle that I have defended, which has been called the "harm to others principle' or 'the harm principle', for short (...) But it does not follow that unsuccessful attempts to perform an act of a type that is very harmful (murder, for example) should not be criminalized! That is a well-intentioned but illogical conclusion drawn from a principle (the harm principle) that gives it no support"
}

consequences given that it would prevent us from punishing certain actions that we consider criminal $^{78}$. Thus, the criminal justice system should be worried about all of the possible harms that may erupt from the violation of a legal rule, not whether there was an ex-post result that resulted from a "lucky" criminal conduct.

Others scholars such as Michael Moore have tried to suggest that the missing causal connection between the action and the death result are sufficient for the attempt to have a lower sentence. As he writes: "Causation matters' seems to be a pretty good candidate for a first principle of morality"79. Nonetheless, a person that acts with extreme due diligence and still causes an undesired result such as a death should be found morally responsible? For example, imagine that a nurse provides a patient his regular medicine, which is found in a labeled recipient for that medicine but, unbeknownst to her, the patient's daughter has introduced cyanide of the same color and shape to the patient's regular medicine. As a result of the cyanide ingestion, the patient dies and the nurse has causally produced that death. In this case, we would never charge the nurse with murder because she didn't have the required means rea. Consequently, causation is not a sufficient condition for a higher punishment scheme. It is for this very same reason that we do not have a strict liability regime in criminal law. We care about what was going on through the person's mind insofar as we want to be able to prevent her decision to take the risk to succeed when shooting at another person. Then again "The law seeks to influence the reasons for which a person acts, but it cannot influence the results of these actions" 80 .

\section{Most of the world's countries have a differential punishment rule}

Another possible counter-argument against the equal punishment thesis relies on the fact that almost every country in the world has attenuated punishment for attempts vis-à-vis consummated crimes. Indeed the great majority of legal systems around the world contain a differential punishment approach ${ }^{81}$. Additionally people intuitively believe that a murder is worse than an attempted murder ${ }^{82}$.

\footnotetext{
${ }^{78}$ Sanford Kadish, The Criminal Law and the Luck of the Draw, J Crim L \& Criminology 679(1994): 695.

${ }^{79}$ Michael S Moore, Causation and Responsibility 81(2008).

${ }^{80}$ Alexander \& Ferzan, Results don't mattersupra note 13, at 152.

${ }^{81}$ George Fletcher, A Crime of Self Defense: Bernhard Goetz and the Law on Trial 82(1988).

${ }^{82}$ Paul H Robinson \& John M Darley, Justice, Liability, and Blame: Community Views and the Criminal Law 23(1995).
} 
However, this may be associated to the fact that most cultures are heavily influenced by retributive thoughts and by an Aristotelian conception of anger. Indeed, the notion of retribution or "dessert" is ubiquitous in the world's religions 83 and thus is pervasive in most countries' criminal law. Most societies favor retribution and payback in punishing that result from some sort of magical thought of "cosmic balance" which may derive from evolution ${ }^{84}$.

In fact, the Aristotelian payback-anger is also widespread in Western Philosophy. For example, Thomas of Aquinas has portrayed a very similar definition of anger to that of Aristotle: "An angry reaction arises only when one has endured some pain, and desires and hopes for revenge" 85 . Descartes too was very much influenced by the Aristotelian conception of anger: "Anger is also a kind of hatred or aversion that we have towards those who have tried to harm not just anyone they happen to meet but us in particular...it is based on an action that affects us and for which we have a desire to avenge ourselves" ${ }^{86}$. Spinoza, along the same lines wrote: "The striving to do evil to him we hate is called Anger" 87 .

As we can observe, this desire for payback and revenge is omnipresent in Western thought and has thus permeated the criminal justice system too. This has also translated itself to the realm of attempts vs. consummated crimes, as Adam Smith acknowledges: "Our resentment against the person who only attempted to a mischief, is seldom so strong as to bear us out in inflicting the same punishment upon him, which we should have thought due if he had actually done it" ${ }^{\prime 8}$. Although, he also suggests that there isn't a rational justification for the differentiation ${ }^{89}$.

\footnotetext{
${ }^{83}$ Nussbaum supra note 19 at 40-43; See also L. Zaibert, Punishment and Retribution 28-40 (2006).

${ }^{84}$ Nussbaum supra note 6 at $24 \& 176$.

85Thomas of Aquinas, Summa Theologica, 1a2ae, q.46, art.1 as cited in P.M.S. Hacker, The Passions A Study of Human Nature 258 (2018).

${ }^{86}$ Descartes, Passions of the Soul, III.199 as cited in P.M.S. Hacker, The Passions A Study of Human Nature 259 (2018).

${ }^{87}$ Baruch Spinoza, Ethics, II.172 as cited in P.M.S. Hacker, The Passions A Study of Human Nature 259 (2018).

${ }^{88}$ Adam Smith, The Theory of Moral Sentiments 188 (reprinted 1976 in Liberty Classics) (1759).

${ }^{89} \mathrm{As}$ he writes: "His real demerit, however, is undoubtedly the same in both cases, since his intentions were equally criminal; and there is in this respect, therefore, an irregularity in the sentiments of all men, and a consequent relaxation of discipline in the laws of, I believe, all nations." Adam Smith, supra note 88at 188.
}

In these lines, one might accept that this may be a compelling argument not to pursue reform in this arena. In conceding this point, Professor Kadish suggests that although this rule may seem irrational: "There are limits, therefore, particularly in a democratic community, to how far the law can or should be bent by reformers to express a moral outlook different from that of the deeply help intuitive perception of the great mass of humanity, irrational though they may seem to some" 90 .

The payback project seems so universal because human beings cannot accept their vulnerability ${ }^{91}$. It feels better to feel like we are in control and that we can gain closure by punishing the offender more harshly ${ }^{92}$. Nonetheless, the criminal justice system should strive for more coherent and rational punishments by not relying on retributive payback. It does not matter if societies or cultures are attached to payback and retributive conceptions of the criminal system. Indeed, "even if people feel overwhelming delight when they have retaliated against the aggressor, that pleasure gives us no reason to endorse or make law around such sadistic and malicious preferences...People can learn to feel pleased by many bad things (racial discrimination, domestic violence, child abuse) and by many silly fantasies (the thought that their cat channels the spirit of a beloved ancestors). These pleasures should be neither here nor there when we perform a normative evaluation"93.

\section{Conclusion}

For too long most of the defenders of the "difference thesis" have tried to justify it based on intuition, even acknowledging that there doesn't seem to be a rational justification for the surplus in punishment between an attempted murder and a murder ${ }^{94}$. We propose that a possible justification can rely on Aristotle's theory of anger, which is pervasive in modern society and in the retributive thought. However, we think that if the purpose of punishment should be forward-looking, with welfareenhancing objectives in mind, the "equivalence thesis" is a more rational and a less arbitrary way of punishing attempted murders.

Now, we do concede that we live in a society where a lot of the criminal justice system is structured around retributive configurations. And it is undeniable that an

\footnotetext{
${ }^{90}$ Sanford Kadish, supra note 78 at 702.

${ }^{91}$ Nussbaum supra note 6 at 29.

${ }^{92} \mathrm{Id}$.

${ }^{93} I d$.

${ }^{94}$ Fletcher supra note 68.
} 
Aristotelian conception of anger does play a major role in other ambits of the criminal law. Nonetheless, we do not think that this is forward-looking perspective for the criminal system to adopt where a "payback" conception of anger should have no role to play.

\section{Bibliography}

\section{Books:}

1. Adam Smith (1754) The Theory of Moral Sentiments (reprinted 1976 in Liberty Classics).

2. Antony R Duff (1996) Criminal Attempts.

3. Antony R Duff (2001) Punishment, Communication, and community.

4. Aristotle, Rhetoric.

5. Baruch Spinoza (1677) Ethics.

6. Bernard Williams (1981) Moral Luck: Philosophical Papers 1973-1980.

7. Descartes (1649) Passions of the Soul.

8. Gabriele Taylor (1985) Pride, Shame, and Guilt: Emotions of Self-Assessment.

9. Gaetano Filangieri (1836) La Ciencia de la Legislación 221-226.

10. George Fletcher (1988) A Crime of Self Defense: Bernhard Goetz and the Law on Trial.

11. George Fletcher (1978) Rethinking Criminal Law.

12. Herbert Morris (1976) On Guilt and Innocence.

13. Heart HLA (1988) Punishment and Responsibility: Essays in the Philosophy of Law.

14. Hyman Gross (1979) A Theory of Criminal Justice.

15. Jeremy Bentham (1781) An Introduction to the Principles of Morals and Legislation 168 (Burns JH \& Hart HLA (Eds.), 1996).

16. Joel Feinberg (2003) Problems at the Root of Law Essays in Legal and Political Theory.

17. Joel Fienberg (1970) Doing and Deserving 33.

18. John Deign (1996) The Sources of Moral Agency 4243.
19. Zaibert L (2006) Punishment and Retribution.

20. La Fave, Scott (1976) Criminal Law.

21. Larry Alexander, Kimberly Ferzan (2009) Crime and Culpability, A Theory of Criminal Law.

22. Nussbaum MC (2014) Anger and Forgiveness: Resentment, Generosity, Justice.

23. Michael S Moore (2008) Causation and Responsibility.

24. Michael S Moore (2010) Placing Blame: A theory of the Criminal Law.

25. Paul H Robinson, John M Darley (1995) Justice, Liability, and Blame: Community Views and the Criminal Law 23.

26. Plato, The Laws.

27. Hacker PMS (2018) The Passions A Study of Human Nature.

28. Thomas Nagel (1979) Mortal Questions.

29. Thomas of Aquinas, Summa Theologica.

\section{Papers:}

30. Bjorn Burkhardt (1986) Is There a Rational Justification for Punishing an Accomplished Crime More Severely Than an Attempted Crime? BYUL Rev 553.

31. Daniel S Nagin (2013) Deterrence in the Twenty-First Century. Crime and Justice 42(1): 199-263.

32. David Lewis (1989) The Punishment That Leaves Something to Chance. Phil \& Pub Aff 18(1): 53-67.

33. David Schmidtz (1987) Deterrence and Criminal Attempts. Canadian Journal of Philosophy 17(3): 615623.

34. Doron Teichman (2011) The Optimism Bias of the Behavioral Analysis of Crime Control. U Ill L Rev 1697-1712.

35. Guyora Binder (2008) The Culpability of Felony Murder. Notre Dame L Rev 83(3): 965-1060.

36. Guyora Binder (2008) Victims and the Significance of Causing Harm. Pace L Rev 28(4): 713-737. 
37. Tedeschi JT, Quigley BM (1996) Limitations of laboratory paradigms for studying aggression. Aggression and Violent Behavior 1(2): 163-177.

38. Goldberg GH, Lerner JS, Tetlock PE (1999) Rage and reason: the psychology of the intuitive prosecutor. Eur J of Soc Psych 29(5-6): 781-795.

39. Jane Hampton (1984) The Moral Education Theory of Punishment. Philosophy \& Public Affairs 13(3): 203238.

40. Ken Levy (2014) Why Retributivism Needs Consequentialism: The Rightful Place of Revenge in the Criminal Justice System. Rutgers L Rev 629.

41. Leo Katz (2000) Why the Successful Assassin Is More Wicked than the Unsuccessful One. Cal L Rev 88(3): 791-812.

42. Lynne N. Henderson (1995) The Wrongs of Victim's Rights. Stan L Rev 37: 937-1021.

43. Michael S Moore (1994) The Independent Moral Significance of Wrongdoing. J of Contemp Legal Studies 237.

44. Michal Davis (1986) Why Attempts Deserve Less Punishment than Complete Crimes. Law \& Phil.

45. Richard A Posner (1985) An Economic Theory of the Criminal Law. Colum L Rev 85(6): 1193-1231.

46. Richard Lowell Nygarrd (1998) Crime, Pain, and Punishment: A Skeptic's View. Dick L Rev 355.

47. Russel Christopher (2004) Does Attempted Murder Deserve Greater Punishment than Murder - Moral Luck and the Duty to Prevent Harm. Notre Dame J L Ethics \& Pub Pol'y 18(2): 419-435.

48. Sanford Kadish (1994) The Criminal Law and the Luck of the Draw. J Crim L \& Criminology 85(4): 679702 .
49. Stephen J Schulhofer (1974) Harm and Punishment: A Critique of Emphasis on the Results of Conduct in the Criminal Law. U Pa L Rev 122: 1497-1607.

50. Steven Sverdlik (1988) Crime and Moral Luck. American Phil Quart 80.

51. Vincent Chiao (2012) Ex Ante Fairness in Criminal Law and Procedure. New Crim L Rev 15(2): 277-332.

\section{Chapters in Books:}

52. Andrew Ashworth (2000) Belief, Intent, and Criminal Liability. In: Eekelaar, Bell (Eds.), Oxford Essays in Jurisprudence.

53. Antony R Duff (1996) Subjectivism objectivism and the role of theory. In: Simester, Smith (Esd.), Harm and Culpability.

54. George P Fletcher (1993) The Nature of Justification. In: Steven Schute, et al. (Eds.), Action and Value in Criminal Law.

55. Herbert Morris (1987) Nonmoral Guilt. In: Ferdinand Schoeman (Ed.), Responsibility, Character, and the Emotions.

56. Larry Alexander, Kimberly Ferzan (2010) Results don't matter. In: Robinson, Garvey, Kessler (Eds.), Criminal Law Conversations.

57. Michael S Moore (1995) The Moral Worth of Retribution in Punishment and Rehabilitation. In: Jeffrie Murphy (Ed.), Punishment and Rehabilitation.

\section{Supreme Court Cases:}

- Furman v. Georgia, 408 U.S. 238, 308 (1972).

\section{Legislation:}

- Model Penal Code (AM. LAW INST., Proposed Official Draft 1962). 